\title{
Pertumbuhan dan Keberlanjutan Konsep Halal Economy di Era Moderasi Beragama
}

\section{The Growth and Sustainability of The Halal Economy Concept in the Religious Moderation Era}

\author{
Fazlurrahman Syarif \\ MBA Islamic Banking and Finance, Bangor University, \\ United Kingdom 2017-2018 \\ fazlursyarif@yahoo.com \\ Naif Adnan \\ Penyuluh Agama Islam Fungsional \\ Kec. Pesanggrahan Kota Jakarta Selatan \\ naifadnan@ymail.com \\ Artikel diterima 15 Juli 2019, diseleksi 1 November 2019, \\ dan disetujui 11 Desember 2019
}

Abstrak: Secara global, konsep Halal Economy telah berkembang melampaui batasbatas agama dan industri halal telah menjadi industri yang kompetitif dalam perdagangan internasional. Konsep Halal Economy, Halal Industry, Halal Products, alasan-alasan pertumbuhan, potret di berbagai negara serta konsep keberlanjutan telah dibahas secara rinci dalam tulisan ini melalui pendekatan analisis-deskriptif. Hasil studi ini menunjukkan bahwa latar belakang agama bukan faktor dominan potensi pertumbuhan Halal Economy akan tetapi kualitas produk telah menjadi tren pola perilaku konsumen. Di samping itu, industri halal berkembang pesat tidak hanya di negara-negara Muslim tetapi juga di negara-negara non-Muslim.

Kata Kunci: Halal Economy, Industri Halal, Negara Muslim dan Non-Muslim 
Abstract: Globally, the concept of the halal economy has grown beyond the boundaries of religion. The halal industry has become a competitive industry in international trade. The concept of halal economy, halal industry, halal products, reasons and growths in various countries as well as sustainability has been detailed discussed in this paper by an analysis-descriptive approach. These studies show that religious background is not the dominant factor for the potential of halal economy growth but the quality of the products has become consumer behaviour trends. Besides, Halal industries are growing rapidly not only in Muslim countries but also in the non-Muslim countries.

Keywords: Halal Economy, Halal Industry, Muslim and Non-Muslim Countries

\section{A. Pendahuluan}

Makanan Halal memainkan peran penting dalam membawa konsep hukum Syariah dalam budaya Barat. ${ }^{1}$ Hukum Syariah Islam adalah sistem hukum yang mengatur setiap aspek kehidupan manusia. ${ }^{2}$ Hukum syariah didasarkan pada Quran, ajaran Nabi Muhammad (Hadis) dan Fatwa (Interpretasi ulama). Syariah dalam bahasa Arab berarti 'jalan'. Mayoritas orang menganggap Syariah sebagai hukum agama saja; selain ajaran agama, prinsip-prinsip syariah juga mencakup hukum keluarga, keuangan, dan bisnis. ${ }^{3}$

'Halal adalah istilah yang menunjuk pada benda atau tindakan yang diperbolehkan untuk menggunakan atau terlibat dalam, menurut hukum Islam'. ${ }^{4}$ Halal dalam bahsa Arab berarti halal atau diizinkan. Haram berlawanan dengan Halal; yang berarti melanggar hukum atau dilarang. ${ }^{5}$ Umumnya, istilah halal digunakan terkait dengan makanan; tapi konsep halal berlaku untuk semua aspek kehidupan. ${ }^{6}$

Pasar halal kini tidak non-eksklusif untuk Muslim, dan telah memperoleh peningkatan penerimaan di antara konsumen non-Muslim yang mengaitkan halal dengan konsumerisme yang etis. Popularitas, 
dan permintaan, produk bersertifikat halal di kalangan konsumen non-Muslim telah meningkat karena lebih banyak konsumen mencari produk-produk berkualitas tinggi, aman dan beretika. Tidak lagi hanya kewajiban agama atau ketaatan bagi Muslim, halal telah menjadi kekuatan pasar yang kuat, menjadi semakin fenomena pasar di seluruh dunia baik bagi Muslim maupun non-Muslim. Tambahan "Halal" pada suatu produk bukan hanya jaminan bahwa produk itu dibolehkan bagi umat Islam, tetapi juga menjadi simbol global untuk jaminan kualitas dan pilihan gaya hidup. Hal Ini terbukti dengan partisipasi dan keterlibatan negara non-Muslim. Banyak negara Barat telah mengakui tren global yang sedang berkembang dalam konsumerisme terhadap produk dan layanan halal, dan kini telah berlomba-lomba untuk mendapatkan pijakan di industri halal.

Pasar konsumen Muslim yang cukup besar dan terus berkembang di seluruh dunia akan terus mendorong pertumbuhan industri halal dan menciptakan sejumlah besar peluang di pasar bagi produk dan layanan halal. Meningkatnya kesadaran konsumen Muslim tentang kewajiban agama mereka juga berkontribusi pada meningkatnya permintaan akan produk dan layanan halal. Demografi umat Islam telah mengalami perubahan signifikan dalam beberapa tahun terakhir. Kini terdapat gelombang semangat religius di antaranya meningkatnya kelas sosial kaum muda, berpendidikan tinggi, dan cerdas yang menganut agama islam dengan gaya hidup global. Hal ini dudukung pula dengan terintegrasinya ke dalam ekonomi global baik sebagai konsumen, wisatawan, investor, produsen, pengecer dan pedagang. Dengan demikian, hal ini telah menciptakan permintaan di belahan dunia pada produk dan layanan yang sesuai dengan nilai-nilai Islam.

Konsumerisme Islam yang berkembang di kalangan Muslim kelas menengah perkotaan di negara-negara dengan populasi Muslim yang besar - seperti Indonesia, Pakistan, dan Turki telah menetapkan tren baru di pasar halal. Hal ini tercermin dalam menjamurnya produk dan layanan bertema agama yang semakin meningkat termasuk perbankan, 
pariwisata, dan fesyen. Oleh karena itu, Muslim modern menggunakan produk halal tidak hanya dapat diterima dari sudut pandang agama, tetapi juga mereka menanamkan rasa bangga dan percaya diri. Industri halal di Indonesia telah menjadi salah satu industri yang paling kompetitif dan memiliki prospek industri bisnis yang menjanjikan. Faktor-faktor kekuatan sosial dan politik internal di Indonesia dengan populasi Muslim terbesar di dunia dan wajibnya mengeluarkan sertifikasi halal bagi produsen.

\section{B. Halal Economy}

Halal Economy adalah kombinasi dari keuangan dan industry halal, yang semakin diakui dalam ekonomi modern. ${ }^{7}$ Istilah umum 'Halal Economy' mulai digunakan setelah World Halal Forum yang diselenggarakan di Kuala Lumpur pada tahun 2011. ${ }^{8}$ Industri Halal dan keuangan Islam saling memiliki keterkaitan dan didasari prinsip-prinsip yang sama dari hukum Islam. Konsep Halal Economy ini cukup baru dibandingkan dengan ekonomi Islam, yang jauh lebih meiliki jangkauan konsep yang lebih luas. ${ }^{9}$

Permintaan untuk industri halal dan keuangan Islam mengalami peningkatan seiring dengan meningkatnya populasi Muslim dan juga adanya penerimaan yang lebih luas terhadap prinsip-prinsip Islam di seluruh dunia. ${ }^{10}$ Menurut Malaysia International Islamic Financial Centre, Secara global, Halal Economy memiliki empat sektor utama: Makanan, Perjalanan, Lifestyle dan Keuangan. ${ }^{11}$ Malaysia sebagai halal hub terkemuka dunia, menunjukkan pertumbuhan yang luar biasa baik industri halal maupun keuangan Islam. Malaysia menduduki peringkat teratas dalam komponen halal economy seperti keuangan Islam, makanan Halal, pariwisata Halal dan kosmetik Halal dan obat-obatan. ${ }^{12}$

\section{Keuangan Islam}

Keuangan Islam merupakan konsep yang lebih dahulu mengalami perkembangan yang pesat dalam ruang lingkup Halal Economy. 
Keuangan Islam modern didirikan di Mesir pada tahun 1963. ${ }^{13}$ Keuangan Islam adalah metode kegiatan perbankan atau pembiayaan yang didasarkan pada hukum Syariah. Secara sederhana, keuangan atau perbankan syariah dapat didefinisikan sebagai perbankan yang bebas bunga. ${ }^{14}$

Keuangan Islam termasuk bank dan lembaga keuangan lainnya beroperasi sesuai dengan hukum Syariah. Keuangan Islam berdiri di atas prinsip syariah seperti menghindari riba (bunga), gharar (ketidakpastian), maysir (perjudian / spekulasi), dan perdagangan komoditas yang telah dilarang; hal itu sesuai dengan konsep halal dan tujuan agama lainnya. ${ }^{15}$ Keuangan Islam juga disebut juga sebagai Ethical Finance karena berdasarkan prinsip-prinsip etika dan agama.

Keuangan Islam beroperasi dengan konsep bagi hasil sesuai ketentuan yang telah disepakati. Ada berbagai jenis kontrak dalam keuangan Islam, di antaranya adalah: Ijarah, Ijarah-wa-iqtina, Mudarabah, Murabahah dan Musyarakah. ${ }^{16}$ Industri keuangan Islam juga meluas ke produk seperti asuransi syariah(takaful) dan obligasi syariah (sukuk). ${ }^{17}$

Keuangan Islam adalah konsep yang berkembang pesat di dunia modern dan merupakan proseskegiatan perbankan atau pembiayaanyang didasarkan pada prinsip-prinsip etika dan agama. ${ }^{18}$ Lembaga keuangan Islam adalah lembaga-lembaga keuangan yang beroperasi sesuai dengan prinsip-prinsip syari'ah. Keuangan Islam menjunjung tinggi sistem yang lebih transparan dan etis yang dapat menguntungkan pertumbuhan ekonomi, mengurangi kemiskinan dan mendorong kemakmuran bersama. Hal ini menarik bagi investor di seluruh dunia, sehingga sistem keuangan berdasarkan hukum syariah tumbuh melampaui batas-batas agama bagi non-Muslim dan di negara-negara non-Muslim. ${ }^{19}$ Pasar keuangan syariah lebih berkembang di negara-negara seperti Dubai dan Malaysia. Negara-negara barat juga mengadopsi Keuangan Islam dan di Inggris, lebih dari 20 bank menawarkan jasa keuangan syariah. 


\section{Industri Halal}

Sebagian besar orang menganggap konsep halal hanya berhubungan dengan makanan saja. Sekarang, industri Halal telah berkembang yang meliputi; produk makanan, makanan jadi, minuman, restoran, rumah potong, media, fashion, kosmetik, farmasi, logistik, perhotelan, dan pariwisata. ${ }^{20}$ Tren perubahan konsumen telah membuka jalan untuk pengembangan pasar halal dan telah diterima secara luas oleh pelanggan non-Muslim. Tingginya tuntutan dan permintaan barang dan jasa halal, banyak negara non-Muslim telah memiliki keberpihakan terkait pasar halal dan juga mulai berinvestasi di industri halal. ${ }^{21}$ Pada saat yang sama, konsep perpaduan antara westernisasi dan kesadaran tentang ajaran agama berimplilaksi pada pembuatan produk atau jasa sesuai dengan standar Islam. ${ }^{22}$

\section{Kategorisasi Halal}

1. Makanan

Industri makanan halal merupakan bagian sektor bisnis terbesar dalam pasar pangan global. Beberapa ekonom berpendapat bahwa di masa depan, pangsa pasar untuk industri makanan halal akan meningkat dengan mempertimbangkan faktor-faktor sebagai berikut: pertumbuhan penduduk muslim, kesadaran di antara orang-orang yang percaya pada makanan halal, serta alasan etika dan safety bagi pelanggan non-Muslim. ${ }^{23}$ Produk makanan halal tidak terbatas pada daging dan unggas, termasuk bahan makanan lainnya seperti kue, biskuit atau es krim yang mengandung produk hewani seperti lard, gelatin atau enzim, makanan kemasan yang mengandung lemak hewan, yaitu berasal dari babi dan produk herbal. ${ }^{24}$ Negara-negara non-Muslim seperti Amerika Serikat, Brazil, Australia dan China adalah manufaktur dan eksportir terbesar makanan halal. ${ }^{25}$ Pada tahun 2018, diperkirakan bahwa pasar makanan halal akan menjadi sekitar \$ 1,6 triliun. 26 
Permintaan Halal industri meningkat dengan meningkatnya populasi Muslim dan juga dengan penerimaan yang lebih luas dari prinsip-prinsip Islam di seluruh dunia. Makanan Halal memainkan peran penting dalam membawa konsep hukum Syariah dalam budaya Barat. Halal memainkan beberapa peran dalam kehidupan muslim di antaranya sebuah keyakinan, sistem etika, dan emosional.

2. Farmasi dan Produk kesehatan

Halal pharmaceuticals memiliki pangsa pendapatan terbesar kedua di pasar halal dunia. Dalam beberapa tahun terakhir, konsep Halal pharmaceuticals telah menunjukkan pertumbuhan yang signifikan. ${ }^{27}$ Produk farmasi dan kesehatan halal sepatutnya harus bebas dari bahan-bahan haram. Alasan pertumbuhan yang luar biasa bukan hanya karena bahan-bahannya bebas dari unsur nonhalal; produk farmasi dan kesehatan halal juga menjamin kualitas produk yang sesuai dengan standar Syariah. ${ }^{28}$ Pasar farmasi Halal terkonsentrasi di Timur Tengah, Afrika Utara, dan Asia Pasifik sedangkan negara-negara seperti Australia, Amerika Serikat dan Singapura telah mulai berinvestasi di produk-produk farmasi dan kesehatan. ${ }^{29}$

Dalam upaya untuk memperkuat integritas dalam pembuatan dan pelayanan obat-obatan dan suplemen kesehatan, Malaysia memperkenalkan standar baru untuk obat-obatan halal. "Standar Malaysia MS2424:2010: Pedoman Umum Farmasi Halal" yaitu meliputi seluruh rantai pasokan industri farmasi mulai dari pemrosesan hingga penanganan, pengemasan, pelabelan, distribusi, penyimpanan, serta tampilan obat-obatan dan suplemen kesehatan.

3. Kosmetik

Kosmetik halal diperkenalkan karena keprihatinan umat Islam pada bahan kosmetik seperti alkohol, lemak babi dan bahan kimia; 
yang dilarang oleh Islam. Kosmetik halal berarti produk yang diproduksi tanpa bahan yang dilarang sesuai hukum Syariah. Kosmetik halal bertujuan untuk mengedepankan kebersihan dan kualitas produk dimana produk kosmetik seperti ini menunjukkan tren pasar yang positif di kalangan konsumen non-Muslim pada umumnya. ${ }^{30}$ Menurut Grand View Research Report, pasar global kosmetik halal akan mencapai USD 52,02 miliar pada tahun 2025. ${ }^{31}$

Penggerak utama untuk permintaan besar dalam kosmetik halal dan produk kecantikan ini berasal dari demografi populasi Muslim profesional muda yang sadar religius dan dinamis. Dalam ruang lingkup kosmetik halal, konsep tersebut mencakup aspek-aspek penting dari produksi seperti bahan-bahan halal dan penggunaan zat-zat yang dibolehkan yang harus dibuat, disimpan, dikemas, dan dikirim sesuai dengan persyaratan Syariah. Menariknya, kosmetik halal juga mendapatkan momentum di antara konsumen modern yang sadar lingkungan dan bersedia membayar premi untuk produk kosmetik organik, alami, dan bersahaja yang sesuai dengan gaya hidup modern mereka.

4. Pariwisata

Pariwisata halal telah berkembang dalam beberapa tahun terakhir untuk memenuhi kebutuhan wisatawan Muslim yang ingin menikmati layanan liburan penuh, yang pada saat yang sama memenuhi persyaratan agama mereka serta adat dan budaya Islam. Sejumlah negara telah mengadaptasi layanan pariwisata mereka untuk memasukkan fasilitas dan akomodasi sesuai dengan kepercayaan religius wisatawan Muslim.

Pariwisata halal dapat didefinisikan sebagai jasa pariwisata dan perhotelan yang sesuai dengan hukum Islam, yang meliputi makanan halal, akomodasi halal, halal town, kegiatan rekreasi untuk pria dan wanita secara terpisah, dll. ${ }^{32}$ Dengan diperkenalkannya Pariwisata Halal, jumlah wisatawan Muslim telah meningkat 
dan negara-negara non-Muslim seperti Australia, Singapura dan Perancis telah memperkenalkan destinasi ramah Muslim. Kini, Malaysia diakui sebagai destinasi pariwisata halal yang ideal. ${ }^{33}$ The Mastercard-HalalTrip Muslim Millennial Travel Report 2017 memproyeksikan peningkatan di masa depan wisatawan Muslim di mana saat ini terdapat 121 million muslim travelers pada tahun 2016, dengan total pengeluaran di sektor parawisata sebesar US $\$ 156$ billion di tahun 2016, 60\% di antaranya berumur di bawah 30 tahun di 2010 sedangkan ke depannya mencapai 156 million pada tahun 2020, US\$220 billion di tahun 2026 and 29\% dari populasi global berumur 15-29 Muslims di tahun 2030.

\section{Faktor-Faktor Penyebab Pertumbuhan Halal Economy}

\section{Pertumbuhan Penduduk Muslim}

Halal Economy akan tumbuh seiring dengan pertumbuhan penduduk Muslim. Menurut Pew Research Center Report, menemukan bahwa dibandingkan dengan agama-agama lain di dunia, populasi Muslim akan tumbuh lebih cepat dan itu akan sama dengan penduduk Kristen pada tahun 2050. ${ }^{34}$ Selain itu, dengan peningkatan populasi, konsep industri halal akan lebih dipopulerkan oleh kalangan non-Muslim juga.

Dalam beberapa tahun terakhir, dengan meningkatnya jumlah Muslim yang makmur, industri halal telah berkembang lebih jauh menjadi persembahan gaya hidup termasuk perjalanan halal dan layanan keramahtamahan. Perkembangan ini telah dipicu oleh perubahan dalam pola pikir konsumen Muslim serta tren konsumen yang etis di seluruh dunia.

\section{Kualitas Produk Halal}

Pasar makanan halal berkembang di seluruh dunia karena peningkatan populasi serta kualitas produk di pasar Halal. ${ }^{35}$ Secara global, lebih dari sebuah konsep agama, halal dianggap sebagai tanda jaminan kualitas. 
Konsumen selalu mencari kualitas yang baik, aman dan produk yang etis; yang dianggap sebagai alasan utama untuk meningkatnya permintaan terhadap barang halal antara pelanggan non-Muslim. ${ }^{36}$

Sebagian besar kosmetik halal berfokus pada bahan-bahan alami, ramah lingkungan, dan fairtrade. Beberapa juga menggunakan komposisi vegan, jadi terdapat peluang untuk memasarkannya kepada non-Muslim. PHB Ethical Beauty dan Ecotrail yang berbasis di Inggris, perusahaan India IbaBrand, menargetkan basis konsumen yang lebih luas dengan produk-produk yang tidak hanya bersertifikat halal tetapi juga bebas dari kekejaman, dan bebas dari bahan kimia yang keras dan organik dan bebas dari produk turunan hewani.

\section{Sertifikasi Halal}

Sertifikasi halal diperkenalkan di Amerika Serikat pada tahun 1960 dengan tujuan untuk memastikan bahwa produk yang dikembangkan stelah memenuhi standar kewajiban agama atau Hukum syariah. Sertifikasi ini akan meningkatkan tingkat kepercayaan antara pelanggan Muslim bahwa produk tersebut halal. Meskipun, sertifikasi halal tidak memiliki standar, persyaratan untuk sertifikasi tersebut telah diakui secara universal. Terlepas dari perspektif agama, sertifikasi halal menjamin kualitas baik dari standar makanan, kosmetik, farmasi maupun produk lainnya. Dengan kata lain, proses sertifikasi adalah 'seal of quality', dimana mengedepankan kepercayaan dan permintaan produk halal di kalangan non-Muslim juga. ${ }^{37}$

Sertifikasi halal memiliki peran vital dalam memastikan kepada konsumen terkait status halal, dan juga dapat memfasilitasi pemasaran produk makanan yang memenuhi persyaratan halal baik untuk konsumsi lokal maupun untuk ekspor. Selain itu, pola konsumsi masyarakat Muslim yang memiliki kecenderungan untuk menggunakan produk yang sudah bersertifikat halal sebagai penanda standarisasi kehalalan produk bahkan jika dihadapkan pilihan dengan cenderung membeli produk yang lebih mahal yang sudah bersertifikat halal. Sehingga secara 
umum, pendekatan halal melalui sertifikat halal menjadi bagian dalam penetrasi pasar.

\section{Ethical Consumerism}

Ethical consumerism berarti membeli produk yang diproduksi secara etis dalam hal ini tidak berbahaya bagi lingkungan dan masyarakat. Terlepas dari prinsip-prinsip agama, Halal juga mengedepankan nilainilai tertentu seperti tanggung jawab sosial, menyelamatkan bumi, keadilan ekonomi dan sosial, kesejahteraan hewan dan investasi yang beretika. ${ }^{38}$ Industri halal sangat menjunjung tinggi nilai-nilai seperti makanan organik, menghindari kekejaman terhadap hewan dan pembangunan yang berkelanjutan. ${ }^{39}$

Kehidupan modern sebagian besar dipengaruhi oleh sains dan teknologi dan selanjutnya hal ini berdampak pada aspek halal dari kegiatan sehari-hari. Hal ini merupakan naluri manusia untuk menginginkan segala yang baik dalam kehidupan dalam bentuk pakaian, makanan, perumahan, interaksi dengan sesama manusia dan lingkungan yang sehat. Dalam Islam, apa pun yang halal membawa kebaikan dan kemakmuran bagi umat manusia dengan tidak merugikan kehidupan dan akibatnya, hal itu mengangkat manusia ke tingkat yang lebih tinggi di dunia ini. Di sisi lain, sesuatu yang haram dianggap tidak murni secara fisik dan spiritual, inferior dan cacat. Haram merupakan unsur berbahaya yang mempengaruhi psikologi manusia. Dengan demikian konsep halal yang mengintegrasikanl dengan sains berfokus pada manfaat, disposisi alami manusia, kesehatan, kebersihan, dan kualitas. Konsep halal merangkum sifat universal Islam.

\section{Potret Halal Economy di Berbagai Negara}

\section{Indonesia}

Indonesia sebagai negara dengan populasi Muslim terbesar di dunia, merupakan pasar potensial bagi industri halal. Sesuai peraturan pemerintah Indonesia, produk harus disertifikasi halal jika ingin dijual 
di dalam negeri. Awalnya, Majelis Ulama Indonesia (MUI) bertanggung jawab untuk mengeluarkan sertifikat halal. ${ }^{40}$ Sesuai dengan UU No 33 tahun 2014 tentang jaminan produk halal, Lembaga Sertifikasi Halal didirikan untuk sertifikasi halal. ${ }^{41}$

Pariwisata adalah sektor industri halal lain yang menjadi nilai tambah utama dengan memberikan kontribusi bagi pertumbuhan ekonomi Indonesia. Pemerintah telah memperkenalkan rencana untuk meningkatkan pariwisata halal di Indonesia dengan berusaha meningkatkan jumlah pengunjung ke 5 juta pada 2019. Di samping itu, Indonesia berupaya untuk memperluas industri keuangan Islam dan untuk menahan setidaknya 15 persen dari pasar global dengan 2023. ${ }^{42}$ Dengan hukum yang efektif untuk mengatur dan memantau praktik halal, Indonesia bisa mempromosikan diri menjadi negara pengekspor halal global yang menonjol. ${ }^{43}$

\section{Malaysia}

Malaysia dianggap sebagai negara pemimpin industri Halal dan ekonomi Islam yang paling berkembang. Pemerintah Malaysia mulai mengatur Halal secara hukum pada awal tahun 1960-an, sehingga menyebabkan negara tersebut menjadi negara dengan pembangunan ekonomi dan tingkat pertumbuhan yang konsisten serta kondisi politik dan sosial yang stabil. ${ }^{44}$ Pada tahun 1974, Pusat Penelitian Divisi Urusan Islam di Kantor Perdana Menteri mulai mengeluarkan surat sertifikasi halal untuk produk yang memenuhi prinsip-prinsip syariah sebagai fondasi dasar demi keberhasilan industri halal. Malaysia pertama kali memperkenalkan dengan medokumentasikan sistem jaminan halal yang sistematis pada tahun $2000 .^{45}$

Pemerintah Malaysia memberlakukan Trade Description Act (TDA) 2011 untuk perlindungan konsumen dari penipuan pelabelan produk halal. ${ }^{46}$ Malaysia mengembangkan pusat sertifikasi produk halal.

Department of Islamic Development Malaysia (JAKIM) adalah satusatunya badan yang berwenang untuk mengeluarkan sertifikasi halal 
yang memiliki otoritas penuh bagi perusahaan untuk menggunakan logo halal pada produk-produk mereka. Pengenalan sertifikasi adalah tonggak dalam pengembangan industri halal di Malaysia. Dalam rangka untuk menjadikan negara global halal hub pada tahun 2020, pemerintah Malaysia telah melakukan banyak inisiatif. ${ }^{47}$ Malaysia berusaha untuk menjadi status berpenghasilan tinggi pada tahun 2020 dan berakselerasi menciptakan rantai produksi yang memiliki nilai tambah dengan menarik investasi di bidang keuangan Islam, industri yang berteknologi tinggi, bioteknologi, dan jasa. ${ }^{48}$

\section{Australia}

Australia hanya memiliki penduduk Muslim yang sedikit, akan tetapi menariknya Australia adalah salah satu eksportir makanan halal terbesar di dunia. Pangsa utama perekonomian negara tersebut tergantung pada ekspor halal. Indonesia, Malaysia, dan kawasan MENA adalah pasar utama dari sektor makanan halal Australia. ${ }^{49}$ Lembaga akreditasi halal diizinkan untuk melakukan sertifikasi halal guna untuk melakukan ekspor daging merah dan produk daging merah. Ada 22 kelompokkelompok Islam yang disetujui oleh pemerintah Australia untuk mengeluarkan sertifikat halal untuk kebutuhan ekspor. ${ }^{50}$ Sertifikasi halal di Australia adalah bisnis yang sangat potensial dan hal ini sangat menguntungkan bagi para pihak yang berwenang dalam mengeluarkan sertifikat halal. ${ }^{51}$

Menurut berbagai sumber, bisnis di industri halal telah mencapai lebih dari 20\% per tahun. Makanan halal dan lifestyle sector diperkirakan akan tumbuh sebesar $6 \%$ pada tahun 2020. ${ }^{52}$

Dengan meningkatnya pasar global pada industri pariwisata halal, Pariwisata Australia juga mengambil inisiatif untuk mempromosikan destinasi ramah Muslim..$^{53}$ Tempat ibadah dan makanan halal telah menjadi fasilitas yang tersedia untuk wisatawan Muslim. Farmasi dan kosmetik halal dapat juga ditemukan di pasar Australia. 
Muslim Community Credit Union Ltd (MCCU) dan Muslim Community Co- Operative (Australia) Ltd menyediakan kebutuhan keuangan dan perbankan untuk komunitas Muslim Australia. Eksistensi MCCA dan MCCU kini menunjukkan hasil yang signifikan dan kini berusaha untuk bertransformasi menawarkan layanan fully-fledged Islamic Bank. ${ }^{54}$

\section{E. Ethics and Sustainability dalam Perspektif Syariah}

Hukum Islam sejalan dengan konsep Halal Economy yang memiliki misi kesejahteraan manusia, hewan, dan lingkungan. ${ }^{55}$ Nilai-nilai etika dan konspep keberlanjutan berpedoman pada hukum Syariah. Hukum Syariah mencakup langkah-langkah untuk mempromosikan pembangunan yang berkelanjutan dan juga menangani hubungan atasan-karyawan, pengadaan, penjualan, periklanan, tender kontrak, perpajakan dan sebagainya. ${ }^{56}$

Dalam perspektif bisnis, etika bisnis Islam memiliki kemiripan dengan pedoman tanggung jawab sosial perusahaan. Hal ini karena etika bisnis Islam dan praktek Corporate Social Responsibility dibangun di atas nilainilai yang kuat, perilaku yang bertanggung jawab, dan keberlanjutan. ${ }^{57}$ Sebagai contoh, tugas atasan untuk memberikan kondisi kerja yang baik dan upah yang adil bagi karyawan. Karyawan diwajibkan untuk melakukan yang terbaik untuk layak mendapatkan pendapatan mereka dan menjunjung tinggi sifat amanah. ${ }^{58}$

Dalam Al-Quran dan Hadis, manusia sepatutnya memanfaatkan sumber daya alam dengan tanggungjawab; yaitu, tidak hanya memikirkan generasi masa depan, akan tetapi juga tetap mengedepankan iman. ${ }^{59}$ Halal economy, sumber daya diatur berdasarkan hukum Syariah, yang mencakup lingkup produksi dan konsumsi; larangan perilaku boros, instruksi untuk merawat ekosistem makhluk hidup, penekanan pada kualitas dan serta tidak hanya menjunjung tinggi kebutuhan material akan tetapi juga kebutuhan spiritual. ${ }^{60}$

Nilai-nilai eko-etika yang terkandung dalam istilah Halal ' dan Tayyib 'cenderung memainkan peran yang semakin relevan bagi perkembangan 
sektor halal dan jelas menjadi komponen nilai tambah bagi produsen dan pemasar. Tayyib, yang berarti sehat dan murni, sangat sesuai dan bersumber pada filsafat dan prinsip-prinsip Islam. ${ }^{61}$

Keberlanjutan secara inheren adalah bagian dari konsep 'Halal dan Tayyib ' dan berpengaruh positif terhadap setiap industri halal. ${ }^{62}$ Sementara halal berarti memastikan bahwa hal-hal yang diproduksi atau disembelih dilakukan secara halal, adapun Tayyib melihat bahwa apa yang kita konsumsi didukung oleh rantai pasokan yang etis. Hal tersebut penting untuk dicatat bahwa Halal itu dan Tayyib berlaku untuk semua aspek kehidupan baik dari keuangan, parawisata bahkan fashion. ${ }^{63}$

\section{F. Penutup}

Terlepas dari latar belakang agama, dunia telah menyaksikan potensi pertumbuhan Halal Economy. Konsep halal tidak hanya terbatas pada sektor makanan akan tetapi telah menjangkau berbagai sektor lain baik kalangan Muslim maupun non-Muslim. Halal Economy telah menjadi pilihan alternatif bagi dunia modern yang kompetitif. Peningkatan kesadaran dan kualitas produk adalah alasan utama di balik pengembangan industri halal. Kurangnya sertifikasi global yang menekankan pada kualitas produk, tentunya dapat mempengaruhi kepercayaan pelanggan. Banyaknya pemain global yang sudah mulai fokus pada produk halal guna mendapatkan keuntungan sebesarbesarnya, seharusnya tetap mengutamakan kualitas produk. Sehingga dengan sertifikasi maka akan berimplikasi pada jaminan global yang efektif.

Industri halal kini telah berevolusi dari produk makanan menuju konsep halal holistik yang mencakup seluruh nilai yang memiliki nilai komersial. Hal ini telah menjadi simbol global bahwa jaminan kualitas serta pilihan gaya hidup bagi Muslim dan non-Muslim. Produk halal yang mendapatkan pengakuan yang lebih luas tidak hanya karena memenuhi persyaratan syariat, tetapi juga aspek kebersihan, sanitasi dan keselamatan. Peningkatan permintaan untuk produk halal yang terlihat 
di sejumlah negara Muslim dan non-muslim telah menjadi bahan bakar pertumbuhan ekonomi yang baik.

Di samping itu, untuk hasil yang lebih maksimal maka diperlukan pola sinergi antara industri halal dan lembaga keuangan Islam. Hal ini karena bisa memunculkan peluang nyata bagi kedua industri untuk saling menguntungkan. Industri halal dapat secara efektif menyerap dana yang tersedia dari lembaga keuangan Islam. Ada beberapa tanda realisasi perlunya konvergensi di kedua industri ini. Malaysia, yang merupakan pusat keunggulan global untuk industri jasa keuangan Islam, juga muncul sebagai pemimpin dalam promosi barang dan jasa halal. Oleh karena itu, agar konvergensi semakin cepat, insentif harus diberikan kepada produsen halal untuk menjaga neraca syariah.

Adapun tantangan untuk lebih mengembangkan sektor halal adalah tentang bagaimana cara terbaik mengintegrasikan produk-produk halal ke dalam kerangka industri global. Kolaborasi aktif dengan paralel utama seperti organik, vegan, etika, dan hak lingkungan menjadi kunci untuk lebih memperkuat nilai produk-produk halal di pasar global.

Selain itu, perbedaan interpretasi pada isu-isu utama seperti metode penyembelihan, pengemasan, logistik, gelatin, perasa makanan dan enzim hewani telah menghambat pengembangan lebih lanjut dari industri halal global. Mempunyai standar halal yang mencakup segala hal dan sistem sertifikasi halal yang diselaraskan yang diadopsi di seluruh dunia perlu mendapatkan perhatian yang khusus. Standar halal global dan sistem sertifikasi akan mempercepat pengembangan produk, memberikan jaminan yang lebih besar kepada konsumen serta mengurangi jumlah sertifikasi ganda.

Tak kalah pentingnya lagi adalah kurangnya pekerja terampil diidentifikasi sebagai salah satu tantangan yang dihadapi industri halal. Semakin banyak pemain industri terlibat dalam bisnis halal, kebutuhan orang-orang yang memenuhi syarat untuk mengelola halal adalah prioritas. Ke depan, industri perlu fokus pada pengembangan 
sumber daya manusia untuk memastikan pertumbuhan industri yang berkelanjutan. Kekurangan profesional yang terampil dan berpengalaman yang dapat bekerja di industri halal, yang jika tidak segera diatasi dapat menghambat pertumbuhan industri serta masalah pengembangan pengetahuan untuk memastikan industri mengikuti tren global terutama pergeseran preferensi konsumen dan tren produksi. Hal ini kemudian menuntut standar halal dan prosedur sertifikasi untuk mengikuti tren perubahan ini. Oleh karena itu, memiliki tenaga kerja terampil dengan keterampilan dan pengetahuan yang diperlukan sangat penting dengan memperbanyak program akademik dan pelatihan di bidang halal yang harus dikembangkan untuk melatih orang-orang yang berkualifikasi terutama dalam penelitian, pengembangan, inovasi dan komersialisasi makanan halal, obat-obatan dan produk konsumen serta layanan yang sesuai dengan Syariah seperti pariwisata dan keramahtamahan. 


\section{Daftar Pustaka}

Aziz, Abdul N, Ibrahim I, and Abdulraof N. 2014. The Need for Legal Intervention within the Halal Pharmaceutical Industry Procedia - Social and Behavioral Sciences 121.

Alserhan BA, 2015. The principles of Islamic Marketing. Routledge.

Ayub M. 2007. Understanding Islamic Finance. John Wiley \& Sons

Dar H, N, Azmi and R, Rahman. 2013. The Global Halal Industry: An Overview' in Global Islamic Finance Report.

El Tiby AM and Grais W. 2014. Islamic Finance and Economic Development: Risk, Regulation, and Corporate Governance. John Wiley \& Sons

Halim MAA and others (eds.) 2014. Consumer Protection of Halal Products in Malaysia: A Literature Highlight Procedia - Social and Behavioral Sciences 121.

Ismaeel M and BlaimK. 2012. Toward Applied Islamic Business Ethics: Responsible Halal Business 31 (10) Journal of Management Development.

Indonesian Law No. 33 of 2014 on Halal Product Certification Malaysian Trade Descriptions Act (TDA) 2011

Mirza AM and Halabi AK. 2003. Islamic Banking in Australia: Challenges and Opportunities. Journal of Muslim Minority Affairs, Vol. 23, No. 2.

Warde I. 2000. Islamic Finance in the Global Economy. Edinburgh University Press.

Yousri A. 2015. Sustainable Development: An Evaluation of Conventional and Islamic Perspectives' in M. Iqbal, Islamic Perspectives on Sustainable Development. Palgrave Macmillan. 
Sumber Internet

'Australia' (Global Islamic Economy Gateway) <https://www. salaamgateway.com/en/country-profile/au/Australia/> accessed 14 Juni 2019.

BBC UK, 'Sharia' (3 September 2009) <http://www.bbc.co.uk/religion/ religions/islam/beliefs/sharia_1.shtml> accessed 17 Juni 2019

Benns M, Halal certification in Australia is big business and worth millions to certifier' (The Daily Telegraph, 16 August 2015) <https://www. dailytelegraph.com.au/news/nsw/halal-certification-in-australiais-big-business-and-worth-millions-to-certifiers/news-story/621b3f 642d22f78a884a365c007e8def $>$ accessed 19 Juni 2019.

Bodiat A, Charity, certainty, and transparency: What the world can learn from Islamic finance (Quartz Media, 13 February 2017) <https:// qz.com/908712/islamic-finance-we-could-learn-a-lot-of-economiclessons-from-how-muslims-use-money/> accessed 14 Juni 2019.

Dr. Komitopoulou E, The Growth of the Halal Market and the Role of Halal Certification (Hot Source, October 2014) <http://www.sgs.com/en/ news/2014/10/the-growth-of-the-halal-market-and-the-role-ofhalal-certification> accessed 14 Juni 2019.

Dudley D, Islamic Finance's growing pains (Economia, 2 March 2017) $<$ http://economia.icaew.com/en/features/march-2017/islamicfinances-growing-pains> accessed 14 Juni 2019.

ElasragH, Halal Industry: Key Challenges and Opportunities (MPRA, 13 January 2016) <https://mpra.ub.uni-muenchen.de/69631/1/MPRA_ paper_69631.pdf> accessed 17 Juni 2019.

'Explore Australia' (Australia tourism, 2017)<http://www.australia. com/en-sg/news/muslim-friendly-australian-holiday-ideas.html> accessed 19 Juni 2019.

'Fact file: What is halal food?' (ABC News, 13 April 2015) <http://www. 
abc.net.au/news/2015-04-14/fact-file-what-is-halal-food/6383242> accessed on 14 Juni 2019.

'Global Halal Cosmetics Market Share, Trend, Segmentation and Forecast 2024' (Industry Today, 20 September 2017) <https://industrytoday. co.uk/utilities-industry-today/global-halal-cosmetics-market-share-trend--segmentation-and-forecast-2024> accessed 14 Juni 2019.

'Growing demand for Halal Pharmaceuticals' (PharmaAsia, 1 September 2014) <https://www.pharmaasia.com/2014/09/growing-demandfor-halal-pharmaceuticals/> accessed 14 Juni 2019.

'Halal Cosmetics Market Worth \$52.02 Billion By 2025' (Grand View Research, February 2017) <https://www.grandviewresearch.com/ press-release/global-halal-cosmetics-market> accessed 14 Juni 2019.

'Halal Economy in Global Markets: An Unstoppable Rise' (The North Africa Post, 23 September 2013) <http://northafricapost.com/4352halal-economy-in-global-markets-an-unstoppable-rise.html> accessed 12 Juni 2019.

'Halal Pharmaceuticals Market to Witness Strong Growth in the Next Decade' (Halal Focus, 10 March 2017) <http://halalfocus.net/halalpharmaceuticals-market-to-witness-strong-growth-in-the-nextdecade/> accessed 14 Juni 2019.

Hisyam MM, Halal Initiatives and Sustainable Living (The Star Online, 7 February 2017) <https://www.thestar.com.my/opinion/columnists/ ikim-views/2017/02/07/halal-initiatives-and-sustainable-livingsustainable-production-and-consumption-are-consistentwith/\#veVSqYHVCUtZU84c.99> accessed 18 Juni 2019.

Islamic Tourism Centre, Malaysia - The world's leading Halal Hub (2017) $<$ http://www.itc.gov.my/tourists/discover-the-muslim-friendlymalaysia/malaysia-the-worlds-leading-halal-hub/> accessed 14 Juni 2019.

ITC, From niche to mainstream Halal goes Global (2015) <http://www. 
intracen.org/publication/From-niche-to-mainstream---Halal-GoesGlobal/> accessed 18 Juni 2019.

'Indonesia' (Global Islamic Economy Gateway) <https://www. salaamgateway.com/en/country-profile/id/indonesia/> accessed 14 Juni 2019.

'Malaysia eyes RM50b Halal exports in 2020' (Global Islamic Economy Gateway, 23 August 2017) <https://www.salaamgateway. com/en/story/malaysia_eyes_rm50b_halal_exports_in_2020SALAAM24082017042422/> accessed 14 Juni 2019.

Mullin G, The Muslim Rulebook-What is Sharia law, how is the Islamic legal system applied in Britain and what punishments does it enforce? (31 March 2017) <https://www.thesun.co.uk/news/3001087/sharia-lawuk-muslims-islamic-legal-system/> accessed 11 Juni 2019.

Murphy J, Halal Certification in Australia: a quick guide (Parliament of Australia, 30 August 2016) <https://www.aph.gov.au/About_ Parliament/Parliamentary_Departments/Parliamentary_Library/ pubs/rp/rp1617/Quick_Guides/HalalCert > accessed 19 Juni 2019.

Noor MA and Shafiai MH, The Axiomatic Approach of Tawhid in Solving Issues in Halal Economy (5th International Symposium on Islam, Civilization, and Science: Islam as a Basis for Civilizational Thought and Development, June 2014) <http://www.ukm.my/hadhari/> accessed 12 Juni 2019.

'Quality conscious buyers spur the growth of \$20-billion halal industry in the US' (IHAF, 7 August 2017) <http://ihaf.org.ae/2017/08/07/ quality-conscious-buyers-spur-the-growth-of-20-billion-halalindustry-in-the-us/> accessed 14 Juni 2019.

Rahim F and Shafii Z, The Nexus of Islamic Finance and Halal Industry: Bridging A Gap in Halal Economy<https://islamicbanker.com/ publications/the-nexus-of-islamic-finance-and-halal-industry> accessed 11 Juni 2019. 
Rosly SA, The Halal industry - Al Ghazali's Ethics in Decision-making (Wahed, 17 September 2017) <https://journal.wahedinvest.com/thehalal-industry-alghazali/> accessed 18 Juni 2019.

Russo A, Halal: Secretly Shoving Sharia Islamic Law Down Your Throat (2 October 2013) < <ttp://churchandstate.org.uk/2013/10/halalsecretly-shoving-sharia-islamic-law-down-your-throat/ > accessed 17 Juni 2019.

Saber L, Can the halal industry contribute to a better environment (Mvslim, July 2017) <http://mvslim.com/can-halal-industry-contributebetter-environment/> accessed 18 Juni 2019.

Swidi A and others (eds.), The mainstream cosmetics industry in Malaysia and the emergence, growth, and prospects of halal cosmetics in 3rd International Conference on International Studies (December 2010) <http://repo.uum.edu.my/2466/> accessed 11 Juni 2019.

The World Bank, Islamic Finance (31 March 2015) <http://www.worldbank. org/en/topic/financialsector/brief/islamic-finance> accessed 14 Juni 2019.

'The Future of World Religions: Population growth projections, 20102050' (Pew Research Center, 2 April 2015) < http://www.pewforum. org/2015/04/02/religious-projections-2010-2050/ > accessed 14 Juni 2019.

'The Halal Economy. Huge Potential for Islamic Finance' (30 September 2014) <http://www.mifc.com> accessed 11 Juni 2019.

Tresna $\mathrm{O}$ and others (eds.), Halal Town as Innovation for Tourism- Islamic University of Indonesia in The IRES International Conference, Seoul, South Korea (December 2016) <http://www.worldresearchlibrary. org/up_proc/pdf/579-148663525414-17.pdf> accessed 17 Juni 2019

U1 Hassan SA, Growing Halal Market in Australia (Suprovat Sydney, 18 November 2017) <http://suprovatsydney.com.au/growing-halalmarket-in-australiabr-by-syed-atiq-ul-hassan-p2640-1.htm> 
accessed 19 Juni 2019.

WIEF Foundation, The endless halal industry (In Focus, 14 September 2016) $<$ https://infocus.wief.org/one-global-system-one-endless-halalindustry/> accessed 18 Juni 2019.

World Bulletin, The Green Muslims - Not Just Halal, but Tayyib (11 March 2017) <http://www.worldbulletin.net/headlines/186086/the-greenmuslims-not-just-halal-but-tayyib> accessed 18 Juni 2019. 


\section{Endnotes}

1. Audrey Russo, 'Halal: Secretly Shoving Sharia Islamic Law Down Your Throat' (2 October 2013) < http://churchandstate.org.uk/2013/10/halal-secretlyshoving-sharia-islamic-law-down-your-throat/ > accessed 18 Juni 2019.

2. BBC UK, 'Sharia' (3 September 2009) <http://www.bbc.co.uk/religion/ religions/islam/beliefs/sharia_1.shtml> accessed 17 Juni 2019.

3. Gemma Mullin, 'The Muslim Rulebook-What is Sharia law, how is the Islamic legal system applied in Britain and what punishments does it enforce?'(31 March 2017) <https://www.thesun.co.uk/news/3001087/sharia-law-uk-muslimsislamic-legal-system/> accessed 19 Juni 2019.

4. B A Alserhan, The principles of Islamic Marketing (Routledge 2015) 16.

5. Hussein Elasrag, 'Halal Industry: Key Challenges and Opportunities' (MPRA, 13 January 2016) <https://mpra.ub.uni-muenchen.de/69631/1/MPRA_ paper_69631.pdf> accessed 17 Juni 2019.

6. Oggy Tresna and others (eds.), 'Halal Town as Innovation for Tourism- Islamic University of Indonesia' in The IRES International Conference, Seoul, South Korea (December 2016) <http://www.worldresearchlibrary.org/up_proc/ pdf/579-148663525414-17.pdf $>$ accessed 17 Juni 2019.

7. M A Noor and M H Shafiai, 'The Axiomatic Approach of Tawhid in Solving Issues in Halal Economy' (5 $5^{\text {th }}$ International Symposium on Islam, Civilization, and Science: Islam as a Basis for Civilizational Thought and Development, June 2014) <http://www.ukm.my/hadhari/> accessed 17 Juni 2019.

8. 'Halal Economy in Global Markets: An Unstoppable Rise' (The North Africa Post, 23 September 2013) <http://northafricapost.com/4352-halal-economyin-global-markets-an-unstoppable-rise.html> accessed 17 Juni 2019.

9. Farlina Rahim and Zurina Shafii, 'The Nexus of Islamic Finance and Halal Industry: Bridging A Gap in Halal Economy'<https://islamicbanker.com/ publications/the-nexus-of-islamic-finance-and-halal-industry $>$ accessed 17 Juni 2019. 
10. A Swidi and others (eds.), 'The mainstream cosmetics industry in Malaysia and the emergence, growth, and prospects of halal cosmetics' in $3^{\text {rd }}$ International Conference on International Studies (December 2010) <http://repo.uum.edu. my/2466/> accessed 18 Juni 2019.

11. Farlina Rahim and Zurina Shafii, 'The Nexus of Islamic Finance and Halal Industry: Bridging A Gap in Halal Economy'<https://islamicbanker.com/ publications/the-nexus-of-islamic-finance-and-halal-industry $>$ accessed 18 Juni 2019.

12. 'The Halal Economy. Huge Potential for Islamic Finance' (30 September 2014) <http://www.mifc.com> accessed 19 Juni 2019.

13. Amr Mohamed El Tiby and W Grais, Islamic Finance and Economic Development: Risk, Regulation, and Corporate Governance (John Wiley \& Sons 2014) 3.

14. Muhammad Ayub, Understanding Islamic Finance (John Wiley \& Sons 2007) 73.

15. Ibrahim Warde, Islamic Finance in the Global Economy (Edinburgh University Press, 2000) $55-59$.

16. The World Bank, 'Islamic Finance' (31 March 2015) <http://www.worldbank. org/en/topic/financialsector/brief/islamic-finance> accessed 20 Juni 2019.

17. Dominic Dudley, 'Islamic Finance's growing pains' (Economia, 2 March 2017) <http://economia.icaew.com/en/features/march-2017/islamic-financesgrowing-pains> accessed 21 Juni 2019.

18. Aneesa Bodiat, 'Charity, certainty, and transparency: What the world can learn from Islamic finance' (Quartz Media, 13 February 2017) <https:// qz.com/908712/islamic-finance-we-could-learn-a-lot-of-economic-lessonsfrom-how-muslims-use-money/> accessed 21 Juni 2019.

19. Dominic Dudley, 'Islamic Finance's growing pains' (Economia, 2 March 2017) <http://economia.icaew.com/en/features/march-2017/islamic-financesgrowing-pains $>$ accessed 20 Juni 2019.

20. Farlina Rahim and Zurina Shafii, 'The Nexus of Islamic Finance and Halal Industry: Bridging A Gap in Halal Economy'<https://islamicbanker.com/ publications/the-nexus-of-islamic-finance-and-halal-industry $>$ accessed 11 
Juni 2019.

21. Hussein Elasrag, 'Halal Industry: Key Challenges and Opportunities' (MPRA, 13 January 2016) <https://mpra.ub.uni-muenchen.de/69631/1/MPRA_ paper_69631.pdf> accessed 17 Juni 2019

22. Prof. H Dar, Dr. N Azmi and R Rahman 'The Global Halal Industry: An Overview' in GlobalIslamic Finance Report (2013) 141.

23. Prof. H Dar, Dr. N Azmi and R Rahman 'The Global Halal Industry: An Overview' in GlobalIslamic Finance Report (2013) 142.

24. 'Fact file: What is halal food?' (ABC News, 13 April 2015) <http://www.abc. net.au/news/2015-04-14/fact-file-what-is-halal-food/6383242> accessed on 14 Juni 2019.

25. Prof. H Dar, Dr. N Azmi and R Rahman 'The Global Halal Industry: An Overview' in GlobalIslamic Finance Report (2013) 145.

26. Aneesa Bodiat, 'Charity, certainty, and transparency: What the world can learn from Islamic finance' (Quartz Media, 24 January 2017) <https://qz.com/888830/ the-worlds-fastest-growing-population-is-also-a-massively-untapped-foodand-fashion-market/> accessed 14 Juni 2019.

27. Prof. H Dar, Dr. N Azmi and R Rahman 'The Global Halal Industry: An Overview' in GlobalIslamic Finance Report (2013) 145.

28. Norazlina Abdul Aziz, Irini Ibrahim, and Nurazlina Abdul Raof, 'The Need for Legal Intervention within the Halal Pharmaceutical Industry' Volume 121, 2014, 124-132 <http://www.sciencedirect.com/science/article/pii/ S1877042814011318> accessed 14 Juni 2019.

29. 'Growing demand for Halal Pharmaceuticals' (PharmaAsia, 1 September 2014) <https://www.pharmaasia.com/2014/09/growing-demand-for-halalpharmaceuticals/> accessed 14 Juni 2019.

30. 'Global Halal Cosmetics Market Share, Trend, Segmentation and Forecast 2024' (Industry Today, 20 September 2017) <https://industrytoday.co.uk/ utilities-industry-today/global-halal-cosmetics-market-share--trend-segmentation-and-forecast-2024> accessed 14 Juni 2019.

31. 'Halal Cosmetics Market Worth \$52.02 Billion By 2025' (Grand View 
Research, February 2017) <https://www.grandviewresearch.com/pressrelease/global-halal-cosmetics-market> accessed 14 Juni 2019.

32. Oggy Tresna and others (eds.), 'Halal Town as Innovation for TourismIslamic University of Indonesia' in The IRES International Conference, Seoul, South Korea (December 2016) <http://www.worldresearchlibrary. org/up_proc/pdf/579-148663525414-17.pdf> accessed 17 Juni 2019

33. Prof. H Dar, Dr. N Azmi and R Rahman 'The Global Halal Industry: An Overview' in GlobalIslamic Finance Report (2013) 146.

34. 'The future of world religions: Population growth projections, 2010-2050' (Pew Research Center, 2 April 2015) < http://www.pewforum.org/2015/04/02/ religious-projections-2010-2050/ > accessed 14 Juni 2019.

35. 'Quality conscious buyers spur the growth of \$20-billion halal industry in the US' (IHAF, 7 August 2017) <http://ihaf.org.ae/2017/08/07/qualityconscious-buyers-spur-the-growth-of-20-billion-halal-industry-in-the-us/> accessed 14 Juni 2019.

36. Hussein Elasrag, 'Halal Industry: Key Challenges and Opportunities' (MPRA, 13 January 2016) <https://mpra.ub.uni-muenchen.de/69631/1/MPRA_ paper_69631.pdf $>$ accessed 17 Juni 2019

37. Dr. Evangelia Komitopoulou, 'The Growth of the Halal Market and the Role of Halal Certification' (Hot Source, * October 2014) <http://www.sgs.com/ en/news/2014/10/the-growth-of-the-halal-market-and-the-role-of-halalcertification> accessed 14 Juni 2019.

38. Hussein Elasrag, 'Halal Industry: Key Challenges and Opportunities' (MPRA, 13 January 2016) <https://mpra.ub.uni-muenchen.de/69631/1/MPRA_ paper_69631.pdf> accessed 17 Juni 2019

39. WIEF Foundation, 'The endless halal industry' (In Focus, 14 September 2016) $<$ https://infocus.wief.org/one-global-system-one-endless-halal-industry/> accessed 14 Juni 2019.

40. 'Indonesia' (Global Islamic Economy Gateway) <https://www. salaamgateway.com/en/country-profile/id/indonesia/> accessed 14 Juni 2019.

41. Prof. H Dar, Dr. N Azmi and R Rahman 'The Global Halal Industry: An 
Overview' in GlobalIslamic Finance Report (2013) 151 - 152.

42. 'Indonesia' (Global Islamic Economy Gateway) <https://www. salaamgateway.com/en/country-profile/id/indonesia/> accessed 14 Juni 2019.

43. Prof. H Dar, Dr. N Azmi and R Rahman 'The Global Halal Industry: An Overview' in GlobalIslamic Finance Report (2013) 151 - 152.

44. Malaysia eyes RM50b Halal exports in 2020' (Global Islamic Economy Gateway, 23 August2017)<https://www.salaamgateway.com/en/story/ malaysia_eyes_rm50b_halal_exports_in_2020-SALAAM24082017042422/> accessed 14 Juni 2019.

45. Islamic Tourism Centre, 'Malaysia - The world's leading Halal Hub' (2017) <http://www.itc.gov.my/tourists/discover-the-muslim-friendly-malaysia/ malaysia-the-worlds-leading-halal-hub/> accessed 14 Juni 2019.

46. MAA Halim and others (eds.) 'Consumer Protection of Halal Products in Malaysia: A Literature Highlight' Procedia - Social and Behavioral Sciences 121 (2014) 68 - 78 <https://ac.els-cdn.com/S1877042814011264/1s2.0-S1877042814011264 main.pdf?_tid=0e294478-e524-11e7-89dd 00000aab0f27\&acdnat=1513733047_c63ad11e827459e24759074a563ccc46 > accessed 14 Juni 2019.

47. Prof. H Dar, Dr. N Azmi and R Rahman 'The Global Halal Industry: An Overview' in GlobalIslamic Finance Report (2013) 148 - 151.

48. 'Malaysia' (Global Islamic Economy Gateway)<https://www.salaamgateway. com/en/country-profile/my/malaysia/> accessed 14 Juni 2019.

49. 'Australia' (Global Islamic Economy Gateway)<https://www.salaamgateway. com/en/country-profile/au/Australia/> accessed 14 Juni 2019.

50. Jaan Murphy, 'Halal Certification in Australia: a quick guide' (Parliament of Australia, 30 August 2016) <https://www.aph.gov.au/About_Parliament/ Parliamentary_Departments/Parliamentary_Library/pubs/rp/rp1617/ Quick_Guides/HalalCert > accessed 19 Juni 2019.

51. Matthew Benns, 'Halal certification in Australia is big business and worth millions to certifiers' (The Daily Telegraph, 16 August 2015) <https://www. dailytelegraph.com.au/news/nsw/halal-certification-in-australia-is-big- 
business-and-worth-millions-to-certifiers/news-story/621b3f642d22f78a884 a365c007e8def $>$ accessed 19 Juni 2019.

52. Syed Atiq Ul Hassan, 'Growing Halal Market in Australia' (Suprovat Sydney, 18 November 2017) <http://suprovatsydney.com.au/growing-halal-marketin-australiabr-by-syed-atiq-ul-hassan-p2640-1.htm> accessed 19 Juni 2019.

53. 'Explore Australia' (Australia tourism, 2017)<http://www.australia.com/ensg/news/muslim-friendly-australian-holiday-ideas.html> accessed 19 Juni 2019.

54. A M Mirza and A K Halabi, 'Islamic Banking in Australia: Challenges and Opportunities. Journal of Muslim Minority Affairs' Journal of Muslim Minority Affairs, Vol. 23, No. 2, (October 2003) 347-359.

55. Latifa Saber, 'Can the halal industry contribute to a better environment' (Mvslim, July 2017)<http://mvslim.com/can-halal-industry-contribute-betterenvironment/> accessed 18 Juni 2019.

56. Prof. Saiful AR, 'The Halal industry - Al Ghazali's Ethics in Decision-making' (Wahed, 17 September 2017) <https://journal.wahedinvest.com/the-halalindustry-alghazali/> accessed 18 Juni 2019.

57. Muatasim Ismaeel and Katharina Blaim, ‘Toward applied Islamic business ethics: responsible halal business' [2012] 31(10) Journal of Management Development 1090 - 1100.

58. Prof. Saiful AR, 'The Halal industry - Al Ghazali's Ethics in Decision-making' (Wahed, 17 September 2017) <https://journal.wahedinvest.com/the-halalindustry-alghazali/> accessed 18 Juni 2019.

59. A Yousri, 'Sustainable Development: An Evaluation of Conventional and Islamic Perspectives' in M. Iqbal, Islamic Perspectives on Sustainable Development (Palgrave Macmillan 2015) 22-57.

60. M Hisyam M, 'Halal initiatives and sustainable living' (The Star Online, 7 February 2017) <https:/www.thestar.com.my/opinion/ columnists/ikim-views/2017/02/07/halal-initiatives-and-sustainableliving-sustainable-production-and-consumption-are-consistentwith/\#veVSqYHVCUtZU84c.99> accessed 18 Juni 2019.

61. World Bulletin, 'The green Muslims - Not just halal, but tayyib' (11 March 
2017) <http://www.worldbulletin.net/headlines/186086/the-green-muslimsnot-just-halal-but-tayyib> accessed 18 Juni 2019.

62. ITC, 'From niche to mainstream Halal goes Global' (2015) <http://www.intracen. org/publication/From-niche-to-mainstream---Halal-Goes-Global/> accessed 18 Juni 2019.

63. World Bulletin, 'The green Muslims - Not just halal, but tayyib' (11 March 2017) <http://www.worldbulletin.net/headlines/186086/the-green-muslimsnot-just-halal-but-tayyib> accessed 18 Juni 2019. 